\title{
АГРОІНЖЕНЕРІЯ
}

УДК 330.131.5:631.526:633.15 (477.7)

DOI https://doi.org/10.32848/agrar.innov.2021.10.18

\section{ЕКОНОМІЧНА ОЦІНКА ВИРОЩУВАННЯ ЛІНІЙ БАТЬКІВСЬКИХ КОМПОНЕНТІВ ТА ГІБРИДІВ КУКУРУДЗИ РІЗНИХ ГРУП ФАО В УМОВАХ ПІВДЕННОГО СТЕПУ УКРАЇНИ}

\author{
ВОЖЕГОВА Р.А. - доктор сільськогосподарських наук, профессор, \\ академік Національної академії аграрних наук України \\ http://orcid.org/0000-0002-3895-5633 \\ Інститут зрошуваного землеробства Національної академії аграрних наук України \\ ЗАБАРА П.П. - здобувач вищої освіти ступеня доктора фрілософії \\ http://orcid.org/0000-0002-6149-3393 \\ Інститут зрошуваного землеробства Національної академії аграрних наук України
}

Постановка проблеми. Аграрний сектор світової економіки в останні роки все більше уваги приділяє вирощуванню кукурудзи, площі якої становлять $20 \%$ у структурі ріллі та забезпечує понад 30\% валового збору зернової маси. В результаті цього дана культура займає лідируючі позиції як за врожайністю зерна, так і за його валовими зборами. Протягом останнього півстоліття посівні площі під кукурудзою зросли в 1,6 рази, врожайність - в 3 рази, а валові збори зерна - в 4,8 рази [1]. Вирощування кукурудзи на зерно відіграє стабілізуючу роль у зерновому комплексі країни, оскільки в несприятливі для інших зернових культур роки ії врожайність $€$ порівняно високою. Технологія вирощування повинна враховувати ґрунтово-кліматичні особливості регіону, що дозволяє найбільш повно використовувати сприятливі та послаблювати або взагалі усувати несприятливі фактори середовища. Переваги кукурудзи полягають також у можливості тривалого збирання без втрат (до одного місяця) та відсутності вилягання на високому фоні внесених добрив або родючих ґрунтах [2]. Вирощування кукурудзи набуло важливого значення. Окрім економічних переваг, кукурудза є попередником і добре вкладається у технологічні процеси вирощування сільськогосподарських культур в господарствах. Порівняно з іншими кукурудза має оптимальне співвідношення продуктивності та витрат, що означає: віддача додаткових коштів найбільш оптимально окуповується прибавками врожаю цієї культури [3].

Аналіз останніх досліджень і публікацій. Кукурудза - одна $з$ найцінніших кормових культур. За врожайністю зерна вона перевищує всі зернові культури. Зерно використовується на продовольчі цілі (20\%), технічні (15-20\%) і на фруражні $(60-65 \%)$. За вмістом кормових одиниць зерно кукурудзи переважає овес, ячмінь, жито. У зерні кукурудзи 65-70\% вуглеводів, 9-12\% білка, 4-8\% рослинної олії (у зародку до 40\%) і лише близько 2\% клітковини. Містяться вітаміни $A$, $\mathrm{B}_{1}, \mathrm{~B}_{2}, \mathrm{~B}_{6}, \mathrm{E}, \mathrm{C}$, незамінні амінокислоти, мінеральні солі і мікроелементи. 3 кукурудзи виготовляють понад 150 харчових і технічних продуктів: борошно, крупу, пластівці, крохмаль, сироп, глюкозу, спирт. Із зародків зерна добувають цінну харчову олію, яка має лікувальні вла- стивості (зменшує вміст холестерину в крові і запобігає захворюванню на атеросклероз) [4].

Економічна ефективність сільськогосподарського виробництва означає одержання максимальної кількості продукції з одного гектара земельної площі при найменших затратах праці і коштів на виробництво одиниці продукції, ефективність виробництва кукурудзи на зерно в ринкових умовах забезпечується за рахунок реалізації заходів щодо збільшення обсягів виробництва за рахунок збільшення урожайності, поліпшення його якості, зниження собівартості і на цій основі отримання максимально можливого рівня рентабельності [5].

Важливим фактором, що визначає рівень ефективності галузі кукурудзівництва, $€$ врожайність. Цей показник характеризує не тільки рівень культури землеробства, а й відображає результат інтенсифікації виробництва та ії економічну доцільність [6].

У комплексі агротехнологічних і організаційно-економічних заходів, які створюють умови для стабілізації обсягів виробництва зерна кукурудзи та підвищення їі конкуренто-спроможності, важливе місце посідає раціональне використання генетичного потенціалу її сортових ресурсів. Процес інтенсифікації виробництва зерна кукурудзи тісно пов'язаний з використанням новітніх досягнень в галузі селекції і насінництва. Впровадження нових більш продуктивних, стійких до несприятливих природно-кліматичних умов і хвороб гібридів кукурудзи, оновлення сортименту насіння високих репродукцій дає змогу збільшити врожайність зерна цієї культури на 20-25\% [7].

Особливої уваги заслуговує раціональний підбір співвідношення гібридів кукурудзи з врахуванням їх скоростиглості та зональних умов вирощування як один із заходів для надійного вирішення проблеми підвищення есрективності виробництва зерна. Дослідженнями доведено, що в структурі гібридного складу доцільно мати до 55\% скоростиглих форм і 45\% середньо- та пізньостиглих. Безумовно, таке співвідношення $€$ орієнтовним і може змінюватись залежно від спеціалізації господарств, їх маркетингової спрямованості та економічної ситуації [7; 8].

У цілому доведено, що для забезпечення надійного зернофуражного балансу раціональне використання 
генетичного потенціалу гібридів кукурудзи потребує особливої уваги. На жаль, товаровиробник реалізує цей потенціал лише наполовину. Кращі гібриди ранньостиглих форм здатні забезпечити 11,0-12,0 т/га зерна, а середньостиглі і середньопізні прості гібриди інтенсивного типу - 12,0-14,0 т/га. Водночас гібриди різних груп стиглості відрізняються не тільки за потенціалом врожайності, а й за вмістом вологи у зерні при збиранні: у ранньостиглих вона нижче в 1,5-2,0 рази від середньо- та пізньостиглих, що зменшує витрати на сушіння і доробку зерна. Залежно від режиму сушіння, вологості та призначення зерна витрати становлять 1,6-3,4 кг рідкого палива на видалення 1\% вологи в розрахунку на 1 т зерна. Економічна ефективність виробництва зерна кукурудзи залежить від комбінованої взаємодії рівня урожайності і вологості зерна, величини яких впливають як на абсолютні затратні елементи, так і на відносні оціночні показники ефективності [9].

Для прискореного впровадження нових інноваційних гібридів важливим елементом $€$ забезпечення насінням ліній - батьківських компонентів насіннєвих господарств для закладення ділянок гібридизації. Тому удосконалення технології вирощування ліній - батьківських компонентів гібридів кукурудзи є актуальним завданням наукових досліджень.

Підвищення ефрективності виробництва продукції рослинництва передбачає збільшення обсягів виробництва продукції з мінімальними витратами на ії одиницю. Отже, необхідно збільшувати врожайність с/г культур та знижувати собівартість продукції.

Мета статті - обґрунтування та удосконалення елементів технології вирощування в умовах зрошення півдня України ліній - батьківських компонентів гібридів кукурудзи різних груп ФАО. Завдання досліджень - встановити економічну оцінку вирощування ліній - батьківських компонентів та гібридів кукурудзи різних груп ФАО, визначити показники економічної ефективність у гібридів та ліній - батьківських компонентів залежно від густоти посіву та обробітку вітчизняними біопрепаратами.

Матеріали та методика досліджень. Метою досліджень було з'ясувати економічну оцінку вирощування ліній - батьківських компонентів та гібридів кукурудзи різних груп ФАО під час вирощування за краплинного зрошення в умовах Південного Степу України.

Відповідно до даних технологічних карт та згідно з додатковими нормативними матеріалами, наведеними в методиці дослідження, нами проведений розрахунок енергетичних витрат і їх ефективності під час вирощування на зерно гібридів кукурудзи різних груп стиглості.

Дослідження проводились протягом 2018-2020 рр. на дослідному полі Інституту зрошуваного землеробства НААН, що розташоване в зоні Інгулецького зрошуваного масиву. Фактор А - різні за групами стиглості лінії-батьківські компоненти: ДК 281 (батьківський компонент гібриду Степовий, ФАО 190), ДК 247 (батьківський компонент гібридів Скадовський, Олешківський, ФАО 290), ДК 411 (батьківський компонент гібридів Чонгар, Ламасан, ФАО 420), ДК 445 (батьківський компонент гібридів Арабат, Віра, Гілея,
ФАО 420); різні за групами стиглості гібриди: Степовий (ФАО 190), Каховський (ФАО 380), Чонгар (ФАО 420), Арабат (ФАО 430).

Фактор В - густота рослин: 70, 80, 90 тис. рослин/га. Фактор C - обробка біологічними препаратами: Bio-gel, Helafit@-combi, що занесені до Реєстру дозволених для використання пестицидів.

Агротехніка вирощування та методика досліджень загальноприйнята для умов зрошення крім факторів, що вивчались. Застосовували краплинне зрошення, з рівнем передполивної вологості ґрунту $80 \%$ НВ у шарі ґрунту 0-50 см [10-12].

Результати досліджень. За результатами аналізу економічних показників вирощування ліній - батьківських компонентів гібридів кукурудзи, найбільша вартість валової продукції з 1 га була одержана на посівах лінії - батьківського компоненту ДК 445 за густоти 70 тис. шт./га та обробітку препаратом Helafit@-combi 182,70 т/га. В цьому варіанті також була встановлена найменша собівартість однієї тонни зерна (табл. 1).

Вартість валової продукції 31 га за різної густоти та обробітку препаратами була максимальною у лінії - батьківського компоненту ДК 445 і склала за варіантами досліду від 119,19 до 182,70 тис. грн/га, дещо меншою у батьківського компоненту ДК 247 122,96 - 141,81 тис. грн/га, менше у батьківського ДК 411 114,55 - 133,11 тис. грн/га, найменшою вартість валової продукції була у лінії ДК 281 - 102,08 - 121,22 тис. грн/ га. Враховуючи виробничі витрати на вирощування кукурудзи, слід відмітити, що найбільше прибутковим та найменше затратним агрозаходом виявився такий фактор як густота рослин. За рахунок підвищення врожайності зерна кукурудзи і зниження технологічних витрат чистий прибуток буде складати 61,86 - 138,19 тис. гривень з гектара.

Найбільший умовно чистий прибуток та рентабельність у батьківського компоненту ДК 281 за густоти рослин 90 тис./га та обробки Helafit@-combi - 79,83 тис. грн/га та 193\% відповідно.

Найбільший умовно чистий прибуток та рентабельність у батьківського компоненту ДК 247 за густоти рос-

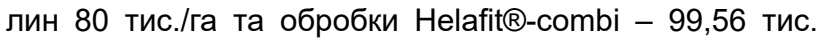
грн/га та 236\% відповідно.

Найбільший умовно чистий прибуток та рентабельність у лінії ДК 411 був за густоти рослин 70 тис./га та обробки Helafit@-combi - 91,70 тис. грн/га та $212 \%$ відповідно.

Найбільший умовно чистий прибуток та рентабельність у лінії ДК 445 за густоти рослин 70 тис./га та обробки Helafit@-combi - 138,19 тис.грн/га та 310\% відповідно.

Нові гібриди, нові технологічні прийоми або їх комплекс, використовуваних в конкретних екологічних умовах, вимагають об'єктивної економічної оцінки їх переваг чи недоліків.

Технологія вирощування гібридів кукурудзи має бути економічно ефективною, тобто в ній повинні використовувати всі виробничі ресурси з метою одержання сільськогосподарської продукції високої якості за мінімальних трудових, матеріальних і фрінансових затрат. 
Економічна ефективність вирощування насіння ліній - батьківських компонентів кукурудзи

Таблиця 1 залежно від густоти та обробки препаратами

\begin{tabular}{|c|c|c|c|c|c|c|c|c|}
\hline $\begin{array}{c}\text { Фактор } \\
\text { A }\end{array}$ & $\begin{array}{c}\text { Фактор } \\
\text { B }\end{array}$ & Фактор C & $\begin{array}{c}\text { Середня } \\
\text { урожай- } \\
\text { ність, т/га }\end{array}$ & $\begin{array}{c}\text { Вартість } \\
\text { валової } \\
\text { продукції, } \\
\text { тис. грн/га }\end{array}$ & $\begin{array}{c}\text { Собівартість } \\
\text { продукції, } \\
\text { тис. грн/т }\end{array}$ & $\begin{array}{c}\text { Витрати, } \\
\text { тис. грн/га }\end{array}$ & $\begin{array}{c}\text { Умовно } \\
\text { чистий } \\
\text { прибуток, } \\
\text { тис. грн/га }\end{array}$ & $\begin{array}{c}\text { Рента- } \\
\text { бельність, } \\
\%\end{array}$ \\
\hline \multirow{9}{*}{$\begin{array}{l}\text { ДК } 281 \\
\text { (Mixed } \\
\text { germ- } \\
\text { plasm) }\end{array}$} & \multirow{3}{*}{70} & $\begin{array}{l}\text { Контроль, } \\
\text { без обробітку }\end{array}$ & 3,52 & 102,08 & 11,43 & 40,22 & 61,86 & 154 \\
\hline & & Bio-gel & 3,59 & 104,11 & 11,26 & 40,43 & 63,68 & 158 \\
\hline & & Helafit@-combi & 3,83 & 111,07 & 10,61 & 40,64 & 70,43 & 173 \\
\hline & \multirow{3}{*}{80} & $\begin{array}{l}\text { Контроль, } \\
\text { без обробітку }\end{array}$ & 3,82 & 110,78 & 10,56 & 40,33 & 70,45 & 175 \\
\hline & & Bio-gel & 3,92 & 113,68 & 10,34 & 40,53 & 73,15 & 180 \\
\hline & & Helafit@-combi & 4,13 & 119,77 & 9,92 & 40,95 & 78,82 & 192 \\
\hline & \multirow{3}{*}{90} & $\begin{array}{l}\text { Контроль, } \\
\text { без обробітку }\end{array}$ & 3,93 & 113,97 & 10,39 & 40,83 & 73,14 & 179 \\
\hline & & Bio-gel & 4,14 & 120,06 & 9,99 & 41,37 & 78,69 & 190 \\
\hline & & Helafit尺-combi & 4,18 & 121,22 & 9,90 & 41,39 & 79,83 & 193 \\
\hline \multirow{9}{*}{$\begin{array}{c}\text { ДК } 247 \\
\text { (Mixed } \\
\text { germ- } \\
\text { plasm) }\end{array}$} & \multirow{3}{*}{70} & $\begin{array}{l}\text { Контроль, } \\
\text { без обробітку }\end{array}$ & 4,45 & 129,05 & 9,32 & 41,50 & 87,55 & 211 \\
\hline & & Bio-gel & 4,59 & 133,11 & 9,07 & 41,65 & 91,46 & 220 \\
\hline & & Helafit@-combi & 4,76 & 138,04 & 8,78 & 41,80 & 96,24 & 230 \\
\hline & \multirow{3}{*}{80} & $\begin{array}{l}\text { Контроль, } \\
\text { без обробітку }\end{array}$ & 4,42 & 128,18 & 9,49 & 41,95 & 86,23 & 206 \\
\hline & & Bio-gel & 4,65 & 134,85 & 9,05 & 42,10 & 92,75 & 220 \\
\hline & & Helafit@-combi & 4,89 & 141,81 & 8,64 & 42,25 & 99,56 & 236 \\
\hline & \multirow{3}{*}{90} & $\begin{array}{l}\text { Контроль, } \\
\text { без обробітку } \\
\end{array}$ & 4,24 & 122,96 & 10,00 & 42,40 & 80,56 & 190 \\
\hline & & Bio-gel & 4,25 & 123,25 & 10,01 & 42,55 & 80,70 & 190 \\
\hline & & Helafit@-combi & 4,43 & 128,47 & 9,64 & 42,70 & 85,77 & 201 \\
\hline \multirow{9}{*}{$\begin{array}{l}\text { ДК } 411 \\
\text { (lodent } \\
\text { germ- } \\
\text { plasm) }\end{array}$} & \multirow{3}{*}{70} & $\begin{array}{l}\text { Контроль, } \\
\text { без обробітку }\end{array}$ & 4,36 & 126,44 & 9,83 & 42,85 & 83,59 & 195 \\
\hline & & Bio-gel & 4,47 & 129,63 & 9,62 & 43,00 & 86,63 & 201 \\
\hline & & Helafit尺-combi & 4,65 & 134,85 & 9,28 & 43,15 & 91,70 & 212 \\
\hline & \multirow{3}{*}{80} & $\begin{array}{l}\text { Контроль, } \\
\text { без обробітку }\end{array}$ & 4,12 & 119,48 & 10,51 & 43,31 & 76,17 & 176 \\
\hline & & Bio-gel & 4,28 & 124,12 & 10,15 & 43,46 & 80,66 & 186 \\
\hline & & Helafit尺-combi & 4,59 & 133,11 & 9,50 & 43,61 & 89,50 & 205 \\
\hline & \multirow{3}{*}{90} & $\begin{array}{l}\text { Контроль, } \\
\text { без обробітку }\end{array}$ & 3,95 & 114,55 & 11,08 & 43,76 & 70,79 & 162 \\
\hline & & Bio-gel & 3,99 & 115,71 & 11,00 & 43,91 & 71,80 & 164 \\
\hline & & Helafit@-combi & 4,26 & 123,54 & 10,34 & 44,06 & 79,48 & 180 \\
\hline \multirow{9}{*}{$\begin{array}{c}\text { ДК } 445 \\
\text { (Mixed } \\
\text { germ- } \\
\text { plasm) }\end{array}$} & \multirow{3}{*}{70} & $\begin{array}{l}\text { Контроль, } \\
\text { без обробітку }\end{array}$ & 5,56 & 161,24 & 7,95 & 44,21 & 117,03 & 265 \\
\hline & & Bio-gel & 5,73 & 166,17 & 7,74 & 44,36 & 121,81 & 275 \\
\hline & & Helafit尺-combi & 6,3 & 182,70 & 7,07 & 44,51 & 138,19 & 310 \\
\hline & \multirow{3}{*}{80} & $\begin{array}{l}\text { Контроль, } \\
\text { без обробітку } \\
\end{array}$ & 4,64 & 134,56 & 9,63 & 44,66 & 89,90 & 201 \\
\hline & & Bio-gel & 4,85 & 140,65 & 9,24 & 44,81 & 95,84 & 214 \\
\hline & & Helafit尺-combi & 6,14 & 178,06 & 7,32 & 44,96 & 133,10 & 296 \\
\hline & \multirow{3}{*}{90} & $\begin{array}{l}\text { Контроль, } \\
\text { без обробітку }\end{array}$ & 4,11 & 119,19 & 10,98 & 45,12 & 74,07 & 164 \\
\hline & & Bio-gel & 4,35 & 126,15 & 10,41 & 45,27 & 80,88 & 179 \\
\hline & & Helafit@-combi & 4,42 & 128,18 & 10,28 & 45,42 & 82,76 & 182 \\
\hline
\end{tabular}

Головним показником економічної ефективності є збільшення виходу продукції з 1 га, зниження собівартості, збільшення прибутку і підвищення рівня рентабельності. Собівартість розраховують діленням затрат на вирощування кукурудзи на вартість одержаної продукції. На основі даних технологічної карти та довідкової літератури нами розрахована економічна ефективність вирощування гібридів кукурудзи різних груп ФАО 
Результати розрахунків економічної ефрективності вирощування кукурудзи свідчать про те, що вартість валової продукції гібридів культури коливалась в дуже широкому діапазоні: від 83,28 тис. грн/га у гібриду Степовий на контрольному варіанті без обробки препаратами за густоти рослин 70 тис. рослин/га до 141,20 тис. грн/га у гібриду Арабат за використання препарату Helafit $(-$ combi та густоти рослин 70 тис. рослин/га (табл. 2).

Економічна ефективність вирощування зерна гібридів кукурудзи залежно від густоти та обробки препаратами

\begin{tabular}{|c|c|c|c|c|c|c|c|c|}
\hline Фактор А & $\begin{array}{c}\text { Фактор } \\
\text { B }\end{array}$ & Фактор C & $\begin{array}{c}\text { Середня } \\
\text { урожай- } \\
\text { ність, т/га }\end{array}$ & $\begin{array}{c}\text { Вартість } \\
\text { валової } \\
\text { продукції, } \\
\text { тис. грн/га }\end{array}$ & $\begin{array}{c}\text { Собівар- } \\
\text { тість } \\
\text { продукції, } \\
\text { тис. грн/т }\end{array}$ & $\begin{array}{c}\text { Витрати, } \\
\text { тис. } \\
\text { грн/га }\end{array}$ & $\begin{array}{c}\text { Умовно } \\
\text { чистий при- } \\
\text { буток, тис. } \\
\text { грн/га }\end{array}$ & $\begin{array}{c}\text { Рента- } \\
\text { бельність, \% }\end{array}$ \\
\hline \multirow{9}{*}{$\begin{array}{l}\text { Степовий } \\
\text { (ФАО 190) }\end{array}$} & \multirow{3}{*}{70} & $\begin{array}{l}\text { Контроль, } \\
\text { без обробітку }\end{array}$ & 10,41 & 83,28 & 2,72 & 28,3 & 54,98 & 194 \\
\hline & & Bio-gel & 10,95 & 87,60 & 2,60 & 28,5 & 59,10 & 207 \\
\hline & & Helafit@-combi & 11,16 & 89,28 & 2,57 & 28,7 & 60,58 & 211 \\
\hline & \multirow{3}{*}{80} & $\begin{array}{l}\text { Контроль, } \\
\text { без обробітку }\end{array}$ & 10,54 & 84,32 & 2,73 & 28,8 & 55,52 & 193 \\
\hline & & Bio-gel & 11,35 & 90,80 & 2,55 & 28,9 & 61,9 & 214 \\
\hline & & Helafit@-combi & 11,78 & 94,24 & 2,47 & 29,1 & 65,14 & 224 \\
\hline & \multirow{3}{*}{90} & $\begin{array}{l}\text { Контроль, } \\
\text { без обробітку }\end{array}$ & 10,69 & 85,52 & 2,70 & 28,9 & 56,62 & 196 \\
\hline & & Bio-gel & 11,57 & 92,56 & 2,52 & 29,1 & 63,46 & 218 \\
\hline & & Helafit@-combi & 11,87 & 94,96 & 2,47 & 29,3 & 65,66 & 224 \\
\hline \multirow{9}{*}{$\begin{array}{c}\text { Каховський } \\
\text { (ФАО 380) }\end{array}$} & \multirow{3}{*}{70} & $\begin{array}{l}\text { Контроль, } \\
\text { без обробітку }\end{array}$ & 11,26 & 90,08 & 2,54 & 28,6 & 61,48 & 215 \\
\hline & & Bio-gel & 12,35 & 98,8 & 2,33 & 28,8 & 70,00 & 243 \\
\hline & & Helafit@-combi & 12,48 & 99,84 & 2,32 & 29,0 & 70,84 & 244 \\
\hline & \multirow{3}{*}{80} & $\begin{array}{l}\text { Контроль, } \\
\text { без обробітку }\end{array}$ & 11,96 & 95,68 & 2,43 & 29,1 & 66,58 & 229 \\
\hline & & Bio-gel & 12,55 & 100,4 & 2,33 & 29,2 & 71,20 & 244 \\
\hline & & Helafit@-combi & 12,89 & 103,12 & 2,28 & 29,4 & 73,72 & 251 \\
\hline & \multirow{3}{*}{90} & $\begin{array}{l}\text { Контроль, } \\
\text { без обробітку }\end{array}$ & 11,68 & 93,44 & 2,50 & 29,2 & 64,24 & 220 \\
\hline & & Bio-gel & 12,41 & 99,28 & 2,36 & 29,3 & 69,98 & 239 \\
\hline & & Helafit $\circledast$-combi & 12,94 & 103,52 & 2,28 & 29,5 & 74,02 & 251 \\
\hline \multirow{9}{*}{$\begin{array}{c}\text { Чонгар } \\
\text { (ФАО 420) }\end{array}$} & \multirow{3}{*}{70} & $\begin{array}{l}\text { Контроль, } \\
\text { без обробітку }\end{array}$ & 16,84 & 134,72 & 1,74 & 29,3 & 105,42 & 360 \\
\hline & & Bio-gel & 16,94 & 135,52 & 1,74 & 29,5 & 106,02 & 359 \\
\hline & & Helafit@-combi & 17,57 & 140,56 & 1,69 & 29,7 & 110,86 & 373 \\
\hline & \multirow{3}{*}{80} & $\begin{array}{l}\text { Контроль, } \\
\text { без обробітку }\end{array}$ & 16,81 & 134,48 & 1,77 & 29,8 & 104,68 & 351 \\
\hline & & Bio-gel & 17,18 & 137,44 & 1,74 & 29,9 & 107,54 & 360 \\
\hline & & Helafit@-combi & 17,36 & 138,88 & 1,73 & 30,1 & 108,78 & 361 \\
\hline & \multirow{3}{*}{90} & $\begin{array}{l}\text { Контроль, } \\
\text { без обробітку }\end{array}$ & 15,15 & 121,20 & 1,97 & 29,9 & 91,30 & 305 \\
\hline & & Bio-gel & 15,84 & 126,72 & 1,90 & 30,1 & 96,62 & 321 \\
\hline & & Helafit@-combi & 16,15 & 129,20 & 1,88 & 30,3 & 98,90 & 326 \\
\hline \multirow{9}{*}{$\begin{array}{c}\text { Арабат } \\
\text { (ФАО 430) }\end{array}$} & \multirow{3}{*}{70} & $\begin{array}{l}\text { Контроль, } \\
\text { без обробітку }\end{array}$ & 17,08 & 136,64 & 1,72 & 29,3 & 107,34 & 366 \\
\hline & & Bio-gel & 17,16 & 137,28 & 1,72 & 29,5 & 107,78 & 365 \\
\hline & & Helafit@-combi & 17,65 & 141,20 & 1,68 & 29,7 & 111,50 & 375 \\
\hline & \multirow{3}{*}{80} & $\begin{array}{l}\text { Контроль, } \\
\text { без обробітку }\end{array}$ & 16,31 & 130,48 & 1,83 & 29,8 & 100,68 & 338 \\
\hline & & Bio-gel & 16,76 & 134,08 & 1,78 & 29,9 & 104,18 & 348 \\
\hline & & Helafit@-combi & 17,21 & 137,68 & 1,75 & 30,1 & 107,58 & 357 \\
\hline & \multirow{3}{*}{90} & $\begin{array}{l}\text { Контроль, } \\
\text { без обробітку }\end{array}$ & 15,15 & 121,20 & 1,97 & 29,9 & 91,30 & 305 \\
\hline & & Bio-gel & 15,54 & 124,32 & 1,94 & 30,1 & 94,22 & 313 \\
\hline & & Helafit@-combi & 15,88 & 127,04 & 1,91 & 30,3 & 96,74 & 319 \\
\hline
\end{tabular}


Собівартість продукції залежала від фракторів, що вивчалися. Так максимальних значень 2,72 тис. грн/т собівартість продукції сягала за вирощування гібриду Степовий на контрольному варіанті, без обробітку за густоти 70 тис. рослин/га, а найнижчою собівартість продукції була у гібриду Арабат за обробки Helafit@combi за густоти 70 тис. рослин/га - 1,68 тис. грн/т.

Розрахунки умовно чистого прибутку виробництва гібридів кукурудзи в умовах півдня України свідчить, що максимальне значення умовно чистого прибутку 41,83 та 42,42 тис. грн/га, спостерігалось у середньопізніх гібридів Чонгар та Арабат за густоти 70 тис. рослин/ га та обробітку препаратом Helafit $\circledast$-combi.

Рівень рентабельності виробництва напряму залежить від вищенаведених показників. За густоти 70 тис. рослин/га та обробітку препаратом Helafit $₫$-combi на середньопізніх гібридах показник рівня рентабельності був максимальний $-373-375 \%$.

Стосовно економічних показників вирощування гібридів кукурудзи за різних густот рослин та обробки препаратами, в середньому за роки досліджень, отримані наступні результати. За використання препаратів вартість валової продукції значно зросла у порівнянні 3 контрольним варіантом і коливалася в межах 87,60-141,20 тис. грн/га, свого максимуму досягала за вирощування гібридів середньопізньої групи.

Рівень собівартості продукції також значним чином залежав від факторів, що вивчалися в досліді. Так, за густоти 70 тис. рослин/га він коливався від 1,69 до 2,72 тис. грн/т, за густоти 80 тис рослин/га від 1,73 до 2,73 тис. грн/т, за густоти 90 тис. рослин/га від 1,88 до 2,70 тис. грн/т.

Звертає на себе увагу той факт, що собівартість продукції максимально коливається, якщо порівнювати її по гібридах різних груп стиглості. Так, у гібриду ранньостиглої групи собівартість склала 2,47-2,73 тис. грн/т, у гібриду середньоранньої групи 2,28-2,54, на гібридах середньопізньої групи 1,69-1,97 тис. грн/т.

Висновки. Ураховуючи виробничі витрати на вирощування ліній - батьківських компонентів гібридів кукурудзи, слід відмітити, що найбільше прибутковим та найменше затратним агрозаходом виявився такий фактор, як густота рослин. За рахунок підвищення врожайності зерна ліній кукурудзи і зниження технологічних витрат чистий прибуток буде складати 61,86 - 138,19 тис. гривень з гектара.

Найбільший умовно чистий прибуток та рентабельність у батьківського компоненту ДК 281 за густоти рослин 90 тис./га та обробки Helafit@-combi - 79,83 тис. грн/ га та $193 \%$ відповідно. Найбільший умовно чистий прибуток та рентабельність у батьківського компоненту ДК 247 за густоти рослин 80 тис./га та обробки Helafit $囚$-combi - 99,56 тис. грн/га та 236\% відповідно. Найбільший умовно чистий прибуток та рентабельність у лінії ДК 411 був за густоти рослин 70 тис./га та обробки Helafit@-combi - 91,70 тис. грн/га та $212 \%$ відповідно. Найбільший умовно чистий прибуток та рентабельність у лінії ДК 445 за густоти рослин 70 тис./га та обробки Helafit $囚-c o m b i ~-~ 138,19$ тис. грн/га та $310 \%$ відповідно.
Найнижча собівартість продукції була у гібриду Арабат за обробки Helafit@-combi за густоти 70 тис. pocлин/га - 1,68 тис. грн/т.

Максимальне значення умовно чистого прибутку 41,83 та 42,42 тис. грн/га - спостерігалось у середньопізніх гібридів Чонгар та Арабат за густоти 70 тис. рослин/га та обробітку препаратом Helafit@-combi.

За густоти 70 тис. рослин/га та обробітку препаратом Helafit@-combi на середньопізніх гібридах показник рівня рентабельності був максимальний - 373-375\%.

\section{СПИСОК ВИКОРИСТАНОÏ ЛІТЕРАТУРИ:}

1. Ільчук М.М., Коновал І.А., Барановська О.Д., Євтушенко В.Д. Розвиток ринку зерна в Україні та його стабілізація. Економіка АПК. 2019. № 4. С. 29-38. URL: http://nbuv.gov.ua/UJRN/E_apk_2019_4_6.

2. ГойсюкЛ.В., ГойсюкС.О.Оцінюванняконкурентоспроможності кукурудзи на зерно та ріпаку сільськогосподарських підприємств України. Інноваційна економіка. http://www.inneco.org/index.php/innecoua/article/ view/723/796 DOI: 10.37332/2309-1533.2021.1-2.12.

3. Грідін О.В. Сучасний стан та тенденції розвитку сфер виробництва, переробки та реалізації зерна: український та загальносвітовий контекст. Східна Європа: економіка, бізнес та управління. 2018. № 3(14). C. 54-62. URL: http://www.easterneuropeebm.in.ua/14-2018-ukr.

4. Дзюбецький Б.В., Черчель В.Ю., Антонюк С.П. Селекція кукурудзи. Генетика і селекція в Україні на межі тисячоліть. Київ : Логос, 2001. Т. 4. С. 571-589.

5. Амбросов В.Я. Питання конкурентоспроможності агрофрормувань. Вісник Харківського національного технічного університету сільського господарства: Економічні науки. 2009. Вип. 85. С. 3-9.

6. Рибка В.С., Шевченко М.С., Ляшенко Н.О. Стан виробництва зерна кукурудзи в Україні та програмне забезпечення ії конкурентоспроможного розвитку на ближню перспективу. Эксклюзивные технологии. 2013. № 5. C. 12-18.

7. Шевченко М.С., Рибка В.С., Ляшенко Н.О. Основні аспекти забезпечення економічної стійкості виробництва зерна кукурудзи в Україні. Хранение и переработка зерна. 2014. № 6. С. 26-29.

8. Лавриненко Ю.О., Марченко Т.Ю., Забара П.П. Селекційні надбання та їх роль в стабілізації виробництва зерна кукурудзи в Україні. Зрошуване землеробство : міжвідомчий тематичний науковий збірник. Херсон : ОЛДІ-ПЛЮС, 2019. Вип. 72. С. 160-174. URL: http://doi.org/10.32848/0135-2369.2019.72.21.

9. Raisa Vozhehova, Tetyana Marchenko, Olena Piliarska, Yurii Lavrynenko, Nataliya Halchenko, Pavlo Lykhovyd. Grain corn product yield and gross value depending on the hybrids and application of biopreparations in the irrigated conditions. Scientific Papers Series Management, Economic Engineering in Agriculture and Rural Development. 2021. Vol. 21, Issue 4. C. 611-619. PRINT ISSN 2284-7995, E-ISSN 2285-3952.

10. Ушкаренко В.О., Нікішенко В.Л., Голобородько С.П., Коковіхін С. В. Дисперсійний і кореляційний аналіз результатів польових дослідів : монографрія. Херсон : Айлант, 2009. 372 с.

11. Ушкаренко В.О., Вожегова Р.А., Голобородько С.П., КоковіхінС.В.Методикапольовогодосліду(Зрошуване землеробство). Херсон : Грінь Д.С., 2014. 448 с. 
12. Vozhehova R.A., Lavrynenko Y.O., Kokovikhin S.V., LykhovydP.V.,Biliaeval.M.,DrobitkoA.V., NesterchukV.V. Assessment of the CROPWAT 8.0 software reliability for evapotranspiration and crop water requirements calculations. Journal of Water and Land Development. Polish Academy of Sciences (PAN) in Warsaw. 2018. No. 39 (X-XII). P. 147-152. URL: http://www.itp.edu.pl/ wydawnictwo/journal; http://www.degruyter.com/view/j/ jwld DOI: 10.2478/jwld-2018-0070.

\section{REFERENCES:}

1. Ilchuk, M.M., Konoval, I.A., Baranovska, O.D., \& Yevtushenko, V.D. (2019). Rozvytok rynku zerna v Ukraini ta yoho stabilizatsiia [Development of the grain market in Ukraine and its stabilization]. Ekonomika APK - Economics of agro-industrial complex. 4. 29-38. URL: http://nbuv.gov.ua/UJRN/E_apk_2019_4_6. [In Ukrainian].

2. Hoisiuk, L.V., \& Hoisiuk, S.O. (2021). Otsiniuvannia konkurentospromozhnosti kukurudzy na zerno ta ripaku silskohospodarskykh pidpryiemstv Ukrainy [Evaluation of the competitiveness of corn for grain and rapeseed of agricultural enterprises of Ukraine]. Innovative economy - Innovatsiina ekonomika. http://www.inneco. org/index.php/innecoua/article/view/723/796 DOI: 10.37332/2309-1533.2021.1-2.12 [In Ukrainian].

3. Hridin, O.V. (2018). Suchasnyi stan ta tendentsii rozvytku sfer vyrobnytstva, pererobky ta realizatsii zerna: Ukrainskyi ta zahalnosvitovyi kontekst [Current state and trends in the development of grain production, processing and sales: Ukrainian and global context]. Skhidna Yevropa: ekonomika, biznes ta upravlinnia Eastern Europe: Economy, Business and Governance, 3(14), 54-62. URL: http://www.easterneurope-ebm. in.ua/14-2018-ukr [In Ukrainian].

4. Dzyubetsky, B.V., Churchel, V.Y., \& Antonyuk, S.P. (2011). Selection of corn [Selektsiia kukurudzy]. Genetics and selection in Ukraine at the turn of the millennium Henetyka i selektsiia v Ukraini na mezhi tysiacholit, 4, 571-589 [In Ukrainian].

5. Ambrosov, V.Ya. (2009). Pytannia konkurentospromozhnosti ahroformuvan [Issues of competitiveness of agricultural formations] Visnyk Kharkivskoho natsionalnoho tekhnichnoho universytetu silskoho hospodarstva: Ekonomichni nauky. - Bulletin of Kharkiv National Technical University of Agriculture: Economic Sciences, 85, 3-9 [In Ukrainian].

6. Rybka, V.S., Shevchenko, M.S., \& Liashenko, N.O. (2013). Stan vyrobnytstva zerna kukurudzy v Ukraini ta prohramne zabezpechennia yii konkurentospromozhnoho rozvytku na blyzhniu perspektyvu. [The state of corn grain production in Ukraine and software for its competitive development in the near future]. Ekskliuzyvnue tekhnolohyy - Exclusive technologies, 5, 12-18 [In Ukrainian].

7. Shevchenko, M.S., Rybka, V.S., \& Liashenko, N.O. (2014). Osnovni aspekty zabezpechennia ekonomichnoi stiikosti vyrobnytstva zerna kukurudzy v Ukraini [Main aspects of ensuring economic sustainability of corn grain production in Ukraine]. Khranenye y pererabotka zerna - Grain storage and processing, 6, 26-29 [In Ukrainian].

8. Lavrynenko, Yu.O., Marchenko, T.Yu., \& Zabara P.P. (2019). Selektsiini nadbannia ta yikh rol v stabilizat- sii vyrobnytstva zerna kukurudzy v Ukraini. [Breeding acquisitions and their role in stabilizing the production of corn grain in Ukraine]. Zroshuvane zemlerobstvo: mizhvidomchyi tematychnyi naukovyi zbirnyk - Irrigated agriculture: interdepartmental thematic scientific collection, 72, 160-174 http://doi. org/10.32848/0135-2369.2019.72.21 [In Ukrainian].

9. Vozhehova, R., Marchenko, T., Piliarska, O., Lavrynenko, Y., Halchenko, N., \& Lykhovyd, P. (2021). Grain corn product yield and gross value depending on the hybrids and application of biopreparations in the irrigated conditions. Scientific Papers Series Management, Economic Engineering in Agriculture and Rural Development, 21(4), 611-619,

10. Ushkarenko, V.O., Nikishenko, V.L., Holoborodko, S.P., \& Kokovikhin, S.V. (2009). Dyspersiinyi i koreliatsiinyi analiz rezultativ polovykh doslidiv. Dispersion and correlation analysis of the results of field experiments [In Ukrainian].

11. Ushkarenko, V.O., Vozhehova, R.A., Holoborodko, S.P., \& Kokovikhin, S.V. (2014). Metodyka polovoho doslidu (Zroshuvane zemlerobstvo) [Methods of field research (Irrigated agriculture)]. [In Ukrainian].

12. Vozhehova, R.A., Lavrynenko, Y.O., Kokovikhin, S.V., Lykhovyd, P.V., Biliaeva, I.M., Drobitko, A.V., \& Nesterchuk, V.V. (2018). Assessment of the CROPWAT 8.0 software reliability for evapotranspiration and crop water requirements calculations. Journal of Water and Land Development. Polish Academy of Sciences (PAN) in Warsaw. 39(X-XII). 147-152. http://www.itp.edu.pl/ wydawnictwo/journal; http://www.degruyter.com/view/j/ jwld DOI: 10.2478/jwld-2018-0070

Вожегова Р.А., Забара П.П. Економічна оцінка вирощування ліній батьківських компонентів та гібридів кукурудзи різних груп ФАО в умовах Південного Степу України

Мета - встановити економічну оцінку вирощування ліній -батьківських компонентів та гібридів кукурудзи різних груп ФАО, визначити показники економічної ефективність у гібридів та ліній -батьківських компонентів залежно від густоти посіву та обробітку вітчизняними біопрепаратами. Методи. Дослідження проводились протягом 2018-2020 рр. на дослідному полі Інституту зрошуваного землеробства НААН, що розташоване в зоні Інгулецького зрошуваного масиву. Фактор А різні за групами стиглості лінії-батьківські компоненти та гібриди різних груп ФАО, Фактор В - густота рослин. Фактор C - обробка біологічними препаратами. Результати. Найбільша вартість валової продукції з 1 га була одержана на посівах лінії -батьківського компоненту ДК 445 за густоти 70 тис. рослин/га та обробітку препаратом Helafit@-combi - 182,70 т/га. У цьому варіанті також була встановлена найменша собівартість однієї тонни зерна. Вартість валової продукції з 1 га за різній густоти та обробітку препаратами була максимальною у ліній-батьківського компоненту ДК 445 і склала за варіантами досліду від 119,19 до 182,70 тис. грн/га, дещо меншою у батьківського компоненту у батьківського компоненту ДК 247 - 122,96 - 141,81 тис. грн/га, менше у батьківського ДК 411 - 114,55 - 133,11 тис. грн/га, найменшою вартість валової продукції була у лінії ДК 281 - 102,08 - 121,22 тис. грн/га. Вартість валової продукції гібридів культури коливалась в дуже широкому 
діапазоні: від 83,28 тис. грн/га у гібриду Степовий на контрольному варіанті без обробки препаратами за густоти рослин 70 тис. рослин/га до 141,20 тис. грн/га у гібриду Арабат за використання препарату Helafit $®$ combi та густоти рослин 70 тис. рослин/га. Висновки. Ураховуючи виробничі витрати на вирощування кукурудзи, слід відмітити, що найбільше прибутковим та найменше затратним агрозаходом виявився такий фрактор, як густота рослин. За рахунок підвищення врожайност зерна кукурудзи і зниження технологічних витрат чистий прибуток складає 61,86 - 138,19 тис. гривень з гектара. Найбільший умовно чистий прибуток та рентабельність у батьківського компоненту ДК 281 за густоти рослин 90 тис./га та обробки Helafit@-combi - 79,83 тис. грн/ га та $193 \%$ відповідно. Найбільший умовно чистий прибуток та рентабельність у батьківського компоненту ДК 247 за густоти рослин 80 тис./га та обробки Helafit $₫$-combi - 99,56 тис. грн/га та 236\% відповідно. Найбільший умовно чистий прибуток та рентабельність у лінії ДК 411 був за густоти рослин 70 тис./га та обробки Helafit@-combi - 91,70 тис. грн/га та 212\% відповідно. Найбільший умовно чистий прибуток та рентабельність у лінії ДК 445 за густоти рослин 70 тис./га та обробки Helafit@-combi - 138,19 тис.грн/га та 310\% відповідно. За густоти 70 тис. рослин/га та обробітку препаратом Helafit@-combi на середньопізніх гібридах показник рівня рентабельності був максимальний - 373-375\%.

Ключові слова: гібриди, лінії - батьківські компоненти, урожайність, рентабельність, умовно чистий прибуток, собівартість.

Vozhegova R.A., Zabara P.P. Economic estimation of cultivation of lines of parent components and hybrids of corn of different groups of FAO in the conditions of the Southern Steppe of Ukraine

Purpose. The aim is to establish an economic assessment of the cultivation of parental components and hybrids of maize of different FAO groups, to determine the cost-effectiveness of hybrids and parental components depending on the density of sowing and treatment with domestic biological products. Methods. The research was conducted during 2018-2020 on the research field of the Institute of Irrigated Agriculture of NAAS, located in the area of Ingulets irrigated massif. Factor A - different maturity lines - parental components and hybrids of different
FAO groups, Factor B - plant density. Factor C - treatment with biological drugs. Results. The highest value of gross output per 1 ha was obtained on crops of the parent component line DK 445 at densities of 70 thousand units/ha and treatment with Helafit $($-combi - 182.70 t/ha. In this case, the lowest cost of one ton of grain was also set. The cost of gross output per 1 ha at different densities and treatment with drugs was the maximum in the lines of the parent component of DC 445 and amounted to experimental variants from 119.19 to 182.70 thousand $\mathrm{UAH} / \mathrm{t}$, slightly less than the parent component in the parent component of DC 247 - 122.96 - 141.81 thousand UAH/t, less than the parent DC $411-114.55-133.11$ thousand $\mathrm{UAH} / \mathrm{t}$, the lowest value of gross output was in the line DC $281-102.08-121.22$ thousand UAH/t. The cost of gross output of hybrids of culture ranged in a very wide range: from 83.28 thousand $\mathrm{UAH} / \mathrm{ha}$ in the hybrid Steppe in the control version without treatment with drugs for plant densities of 70 thousand plants/ha to 141.20 thousand $\mathrm{UAH} / \mathrm{ha}$ in the hybrid Arabat using Helafit@-combi and plant density 70 thousand plants/ha. Conclusions. Given the production costs of growing corn, it should be noted that the most profitable and least expensive agricultural measure was such a factor as plant density. Due to the increase in corn grain yield and reduction of technological costs, the net profit is $61.86-138.19$ thousand hryvnias per hectare. The highest conditionally net profit and profitability of the parent component of DC 281 for plant densities of 90 thousand/ ha and Helafit $\AA$-combi treatment -79.83 thousand UAH/ ha and $193 \%$, respectively. The highest conditionally net profit and profitability of the parent component of DK 247 for plant densities of 80 thousand /ha and Helafit $₫$-combi treatment - 99.56 thousand $\mathrm{UAH} /$ ha and $236 \%$, respectively. The largest conditionally net profit and profitability in the line of DC 411 was for plant densities of 70 thousand/ha and Helafit $@-c o m b i$ treatment -91.70 thousand $\mathrm{UAH} / \mathrm{ha}$ and $212 \%$, respectively. The highest conditionally net profit and profitability in the line of DK 445 for plant densities of 70 thousand/ha and Helafit $囚$-combi treatment - 138.19 thousand UAH/ ha and $310 \%$, respectively. At a density of 70 thousand plants/ha and treatment with Helafit $\AA$-combi on mediumlate hybrids, the rate of return was maximum - 373-375\%.

Key words: hybrids, parental lines, productivity, profitability, conditionally net profit, prime cost. 